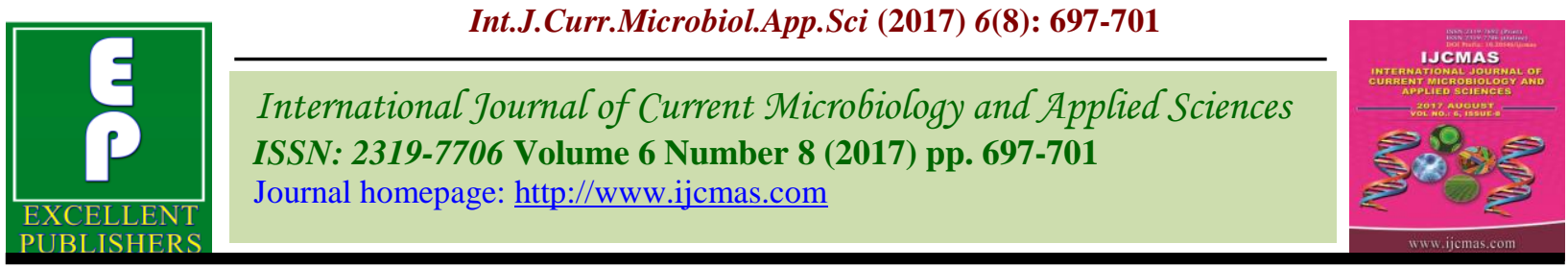

Original Research Article https://doi.org/10.20546/ijcmas.2017.608.088

\title{
Phosphorus Uptake by Fodder Maize (Zea mays L.) Influenced by Different Levels of Lead and Farm Yard Manure Grown in Texturally Different Soils
}

\author{
V.J. Patel ${ }^{1}$, J.C. Patel $^{2}$, S.V. Rathod ${ }^{2 *}$ and B.J. Mori ${ }^{2}$ \\ ${ }^{1}$ Main Maize Research Station, AAU, Anand, India \\ ${ }^{2}$ Department of Soil Science and Agricultural Chemistry, B.A. College of Agriculture, \\ AAU, Anand - 388110, India \\ *Corresponding author
}

\begin{tabular}{|c|c|}
\hline & A B S T R A C T \\
\hline $\mathbf{K e}$ & A pot experiment was laid out to investigate the impact of different levels of Lead and \\
\hline $\begin{array}{l}\text { Lead, Farm Yard } \\
\text { Manure, } \mathrm{Pb} \\
\left(\mathrm{NO}_{3}\right)_{2} \\
\text { Phosphorus } \\
\text { uptake. }\end{array}$ & $\begin{array}{l}40 \mathrm{ppm}) \text { applied as } \mathrm{Pb}\left(\mathrm{NO}_{3}\right)_{2} \text { and two levels of FYM }\left(0 \text { and } 10 \mathrm{t} \mathrm{ha}^{-1}\right) \text { applied on two } \\
\text { texturally different soils (Loamy sand and Clayey soils). The Result revealed that } \\
\text { phosphorus uptake by plant components and total } \mathrm{P} \text { uptake was significantly decreased } \\
\text { with increased Pb levels }(0 \text { to } 40 \mathrm{ppm}) \text {. This might be due to with increasing dose of Pb }\end{array}$ \\
\hline Article Info & $\begin{array}{l}\text { reducing the uptake of phosphorus through raising the level of toxicity. When organic } \\
\text { matter with reactive groups such as hydroxyl, phenoxy and carboxyl effectively controls }\end{array}$ \\
\hline $\begin{array}{l}\text { Accepted: } \\
\text { 04 June } 2017 \\
\text { Available Online: } \\
10 \text { August } 2017\end{array}$ & $\begin{array}{l}\text { the adsorption and complexation of } \mathrm{Pb} \text { and the activity of } \mathrm{Pb} \text { in the soil, the application of } \\
\mathrm{FYM} @ 10 \mathrm{th} \mathrm{h}^{-1} \text { gave significantly higher uptake of phosphorus as compared to no FYM } \\
\text { explicated plot. In addition, applied FYM has not increased the removal of } \mathrm{P} \text { by plant } \\
\text { along with increasing doses of } \mathrm{Pb} \text { but its reduced the toxicity of this metal meanwhile }\end{array}$ \\
\hline
\end{tabular}

\section{Introduction}

Lead is non essential element for plants from the view point of plant nutrition. It is one of the major chemical pollutant of the environment and is highly toxic to human beings and animals because it mimics many aspects of the metabolic behavior of the nutrient and inhibits much enzyme system. However, it sets added in the agricultural soil mainly through irrigation with sewage water and industrial effluents from battery, smelter, paint and pigment, fertilizer, pesticides and petroleum. Lead compounds are major pollutants emitted by automobiles. Sewage sludge containing large quantities of $\mathrm{Pb}$ and other metals is regularly discharged on to field and garden soils due to increase trends in urbanization (Paivoke, 2002). The nutrient concentration in plant is also affected by lead. Lead can be accumulated in plant organs and agricultural products (Burzynski, 1987; Mahmoud and El-Beltagy, 1998) and consequently enter human food chain (Wagner, 1993).

FYM is the source of primary, secondary and micronutrient to the plant growth. Farm yard manure (FYM) improves the crop production (Kaihura et al., 1999) and can be used to 
reduce heavy metals hazards in plants (Yassen et al., 2007). Organic matter with reactive groups such as hydroxyl, phenoxy and carboxyl effectively controls the adsorption and complexation of heavy metal and the activity of metal in the soil (Lee et al., 2004; Mahmood, 2010). Maize (Zea mays L.) is grown for both grain and fodder. It is the ideal forage crop having quick growing habit, high yielding ability, palatability, nutritive value and acceptable to the cattle at any stage of growth. Maize is the indicator crop so it has been selected as a test crop for studying the behaviour of lead in presence of FYM in two different soils.

\section{Materials and Methods}

A pot experiment was conducted to study the effect of varying levels of $\mathrm{Pb}(0,5,1020$ and $40 \mathrm{ppm})$ applied as $\mathrm{Pb}\left(\mathrm{NO}_{3}\right)_{2}$ and two levels of FYM (F0 and F1 i.e. 0 and $10 \mathrm{t} \mathrm{ha}^{-1}$ ) on phosphorus uptake by fodder maize cv. AFRICAN TALL on two types of soil Loamy sand $\left(\mathrm{S}_{1}\right)$ of Agronomy farm of Anand and Clayey soil $\left(S_{2}\right)$ of Karvan village Gujarat. The physico-chemical properties of the soil are given in the table 1 . The experiment was conducted in Factorial CRD with three replications. The pots were brought to FC and 10 seeds of maize were sown in each pot. After germination, maize plants were thinned to 5 plants per pot.

Pots were regularly watered and weed free condition was maintained till 60 DAS required for maize crop. Irrigation at maturity, the plants were uprooted carefully and after oven drying at $650^{\circ} \mathrm{C}$, the dry matter yield of plant components was recorded.

The total phosphorus uptake in plant samples was analyzed following vanadomolybdophosphoric acid yellow colour method (Jackson, 1973). The data on uptake was subject to statistical analysis as per methods suggested by Steel and Torrie (1982). Farm Yard Manure (FYM) was analyzed for its OC, $\mathrm{N}, \mathrm{P}, \mathrm{K}, \mathrm{Ca}, \mathrm{Mg}$, micronutrient and heavy metal contents, whereas di ammonium phosphate (DAP) was analysed only for $\mathrm{Pb}$ content before incorporation in to the soil. The results obtained are given below (Table 2 ).

\section{Results and Discussion}

The results gained from the present experiment and relevant discussion has been summarized under the following head.

\section{Effect of $\mathrm{Pb}$ levels}

A significant decreased in uptake by shoot and roots and total $\mathrm{P}$ were noted with increasing $\mathrm{Pb}$ application (Table 4).

The P uptake decreased with increasing levels of $\mathrm{Pb}$ from 0 to $40 \mathrm{ppm}$ in shoot (102.21 to $59.75 \mathrm{mg} \mathrm{pot}^{-1}$, root 48.61 to $27.62 \mathrm{mg} \mathrm{pot}^{-1}$ and total P 150.82 to $87.36 \mathrm{mg} \mathrm{pot}^{-1}$. Kansal et al., (1992) was observed that phosphorus content was found to be negatively correlated with soil $\mathrm{Pb}$ in maize crop. This is in agreement with Walker et al., (1997) who reported that $\mathrm{Pb}$ decreased the uptake of phosphorus in maize.

\section{Effect of FYM}

Result (Table 4) revealed that $\mathrm{P}$ uptake by plant parts were significantly higher in FYM treated soil $\left(\mathrm{F}_{1}\right)$ as compared to no FYM application $\left(\mathrm{F}_{0}\right)$.

The application of organic manure has increasing the phosphorus uptake as compared to no manure application. Similar effects of organic manures were also recorded by Prasad et al., (2010) in maize grown in Alfisols of Jharkhand. Sidhu and Narwal (2003) reported that application of FYM in $\mathrm{Pb}$ treated soil increased the $\mathrm{P}$ content in maize. 


\section{Effect of soil}

The clayey soil $\left(\mathrm{S}_{2}\right)$ registered higher $\mathrm{P}$ uptake by shoot, root and total as compared to that in loamy sand soil $\left(\mathrm{S}_{1}\right)($ Table 4$)$.

It might be ascribed that the low availability of $\mathrm{Pb}$ in clayey soil than loamy sand soil and less toxic effect on P uptake.

\section{Interaction effect}

\section{Effect of F X S interaction}

It is indicated from the result (Table 3) that the shoots of maize grown in FYM treated clayey $\left(\mathrm{F}_{1} \mathrm{~S}_{2}\right)$ soil accumulated significantly more $\mathrm{P}$ over all other treatments. The lowest $\mathrm{P}$ uptake was found in $\left(\mathrm{F}_{0} \mathrm{~S}_{1}\right)$ treatments combination.

Table.1 Initial physico-chemical properties of the experimental soil

\begin{tabular}{|c|c|c|c|c|}
\hline Sr.No & \multicolumn{3}{|c|}{ Characteristics } & Reference \\
\hline \multirow{2}{*}{$\mathbf{A}$} & Characteristics & & & \\
\hline & Mechanical Analysis & Anand & Karvan & \\
\hline 1 & Coarse sand $(\%)$ & 4.47 & 7.80 & \multirow{6}{*}{ Piper (1966) } \\
\hline 2 & Fine sand $(\%)$ & 77.94 & 22.71 & \\
\hline 3 & Silt $(\%)$ & 10.95 & 21.73 & \\
\hline 4 & Clay (\%) & 6.12 & 47.26 & \\
\hline 5 & Texture & Loamy sand & Clayey & \\
\hline 6 & WHC (\%) & 33.00 & 51.00 & \\
\hline 7 & CEC [cmol (p+) kg-1] & 17.00 & 32.50 & Jackson (1973) \\
\hline $\mathbf{B}$ & \multicolumn{4}{|l|}{ Chemical Analysis } \\
\hline 1 & $\mathrm{pH}(1: 2.5)$ & 7.4 & 8.02 & \multirow{2}{*}{ Jackson (1973) } \\
\hline 2 & $\mathrm{EC}(1: 2.5) \mathrm{dS} \mathrm{m}^{-1}$ & 0.13 & 0.62 & \\
\hline 3 & Organic carbon $(\%)$ & 0.386 & 0.451 & Walkley and Black (1934) \\
\hline 4 & Available $\mathrm{P}_{2} \mathrm{O}_{5}\left(\mathrm{~kg} \mathrm{ha}^{-1}\right)$ & 26.34 & 34.28 & Olsen et al., (1954) \\
\hline 5 & Available $\mathrm{K}_{2} \mathrm{O}\left(\mathrm{kg} \mathrm{ha}^{-1}\right)$ & 213.17 & 323.49 & Jackson (1973) \\
\hline 6 & Available S (ppm) & 4.72 & 4.51 & Chesnin and Yien (1950) \\
\hline 7 & DTPA- Pb (ppm) & 0.20 & 0.34 & Lindsay and Norvell (1978) \\
\hline
\end{tabular}

Table.2 Chemical composition of FYM and fertilizer used in experiment

\begin{tabular}{|l|l|l|l|l|l|l|l|l|l|l|l|}
\hline Elements & OC & $\mathbf{N}$ & $\mathbf{P}$ & $\mathbf{K}$ & $\mathbf{C a}$ & $\mathbf{M g}$ & $\mathbf{Z n}$ & $\mathbf{F e}$ & $\mathbf{C u}$ & $\mathbf{M n}$ & $\mathbf{P b}$ \\
\hline \multicolumn{9}{|c|}{$\mathbf{( \% )}$} \\
\hline FYM & 27.7 & 0.61 & 0.34 & 0.30 & 0.53 & 0.61 & 136 & 545 & 193 & 57 & 0.42 \\
\hline DAP & - & 18 & 46 & - & - & - & - & - & - & - & - \\
\hline
\end{tabular}

Table.3 Interaction effect of FYM and soil on P uptake by maize

\begin{tabular}{|c|c|c|}
\hline \multirow{2}{*}{ Types of soil } & \multicolumn{2}{|c|}{ FYM levels } \\
\cline { 2 - 3 } & $\mathbf{F}_{\mathbf{0}}$ & $\mathbf{F}_{\mathbf{1}}$ \\
\cline { 2 - 3 } & \multicolumn{2}{|c|}{ P uptake by Shoot } \\
\hline $\mathrm{S}_{1}$ & 60.46 & 81.79 \\
\hline $\mathrm{S}_{2}$ & 83.68 & 94.67 \\
\hline F X S & SEm \pm & 2.11 \\
& CD @ 5\% & 6.04 \\
\hline
\end{tabular}


Table.4 Effect of lead and FYM on P uptake by maize grown in different soils

\begin{tabular}{|c|c|c|c|}
\hline \multirow[t]{2}{*}{ Treatment } & \multicolumn{3}{|c|}{ P uptake (mg pot $\left.{ }^{-1}\right)$} \\
\hline & Shoot & Root & Total \\
\hline \multicolumn{4}{|c|}{ Levels of $\mathrm{Pb}(\mathbf{P b})$} \\
\hline $\mathrm{Pb}_{0:} 0 \mathrm{ppm}$ & 102.21 & 48.61 & 150.82 \\
\hline $\mathrm{Pb}_{1}: 5 \mathrm{ppm}$ & 90.62 & 43.57 & 134.19 \\
\hline $\mathrm{Pb}_{2}: 10 \mathrm{ppm}$ & 79.70 & 39.71 & 119.42 \\
\hline $\mathrm{Pb}_{3:} 20 \mathrm{ppm}$ & 68.46 & 34.72 & 103.19 \\
\hline $\mathrm{Pb}_{4:} 40 \mathrm{ppm}$ & 59.75 & 27.62 & 87.36 \\
\hline $\mathrm{SEm} \pm$ & 2.36 & 0.64 & 2.74 \\
\hline CD@ @ $5 \%$ & 6.75 & 1.82 & 7.82 \\
\hline \multicolumn{4}{|c|}{ Levels of FYM (F) } \\
\hline $\mathrm{F}_{0:} 0 \mathrm{tha}^{-1}$ & 72.07 & 36.38 & 108.45 \\
\hline $\mathrm{F}_{1:} 10 \mathrm{tha}^{-1}$ & 88.23 & 41.31 & 129.55 \\
\hline SEm \pm & 1.49 & 0.40 & 1.73 \\
\hline CD @ 5\% & 4.27 & 1.15 & 4.95 \\
\hline \multicolumn{4}{|c|}{ Types of soil (S) } \\
\hline$S_{1:}$ Loamy sand & 71.13 & 35.27 & 106.40 \\
\hline $\mathrm{S}_{2:}$ Clayey & 89.18 & 42.42 & 131.60 \\
\hline SEm \pm & 1.49 & 0.40 & 1.73 \\
\hline CD@ @ $5 \%$ & 4.27 & 1.15 & 4.95 \\
\hline CV \% & 10.22 & 5.69 & 7.97 \\
\hline
\end{tabular}

Table.5 Interaction effect of lead and soil on P uptake $\left(\mathrm{mg} \mathrm{pot}^{-1}\right)$ by of maize

\begin{tabular}{|c|c|c|c|c|c|}
\hline \multirow{3}{*}{ Types of soil } & \multicolumn{5}{|c|}{ Pb levels } \\
\hline & $\mathrm{Pb}_{0}$ & $\mathrm{~Pb}_{1}$ & $\mathrm{~Pb}_{2}$ & $\mathrm{~Pb}_{3}$ & $\mathrm{~Pb}_{4}$ \\
\hline & \multicolumn{5}{|c|}{ P uptake by root } \\
\hline $\mathrm{S}_{1}$ & 42.30 & 39.08 & 35.34 & 32.51 & 27.12 \\
\hline$S_{2}$ & 54.93 & 48.05 & 44.08 & 36.94 & 28.12 \\
\hline \multirow[t]{2}{*}{ Pb X S } & \multirow{2}{*}{\multicolumn{5}{|c|}{$\begin{array}{ll}\text { SEm } \pm & 0.90 \\
\text { CD @ 5\% } & 2.58\end{array}$}} \\
\hline & & & & & \\
\hline$S_{1}$ & 130.38 & 119.70 & 107.06 & 94.73 & 80.10 \\
\hline $\mathrm{S}_{2}$ & 171.27 & 148.68 & 131.77 & 111.64 & 94.62 \\
\hline Pb X S & \multicolumn{5}{|c|}{$\begin{array}{ll}\text { SEm } \pm & 3.87 \\
\text { CD @ 5\% } & 11.07 \\
\end{array}$} \\
\hline
\end{tabular}

\section{Effect of $\mathrm{Pb}$ X S interaction}

The $\mathrm{P}$ uptake by roots and the total $\mathrm{P}$ were significantly higher when they grown in clayey soil $\left(\mathrm{S}_{2}\right)$ as compared to loamy sand soil $\left(\mathrm{S}_{1}\right)$ under different $\mathrm{Pb}$ levels (Table 5).
The lowest $\mathrm{P}$ uptake was noticed under 40 $\mathrm{ppm} \mathrm{Pb}$ application to the soil in all the cases.

In conclusion, the result of pot experiment revealed that phosphorus uptake in plant components significantly decreased when 40 
ppm $\mathrm{Pb}$ was added. The total phosphorus uptake by maize significantly decreased at each level of $\mathrm{Pb}$ application. Among the soil, plant depleted more phosphorus when grown in clayey soil than loamy sand soil. The phosphorus removal was significantly higher in FYM treated soil as compare to no FYM treated soil.

\section{References}

Burzynski, M. 1987. The uptake and transpiration of water and the accumulation of lead by plants growing on lead chloride solutions. Acta Societatis Botanicorum. Poloniae, 56: 271-280.

Jackson, M.L. 1973. Soil chemical analysis.Prentice hall of India Pvt Ltd., Korndorfer, G. H., Coelho, M.N., Synder, G.H. and Mizutani, C.T. 1999. An evaluation of soil extractants for silicon availability in upland rice. 1. Plant Nutr., 23: 101-106.

Kaihura, B.S., Kullaya, I.K., Kilasara, M., Aune, J.B., Singh, B.R., Lal, R. 1999. Soil quality effects of accelerated erosion and management systems in three eco-regions of Tanzania. Soil Tillage Res., 53: 59-70.

Lee, T.M., Lai, H.Y. and Chen, Z.S. 2004. Effect of chemical amendments on the concentration of $\mathrm{Cd}$ and $\mathrm{Pb}$ in long term contaminated soil. Chemosphere, 57:
1459-1471.

Mahmoud, W.H. and El-Beltagy, A. 1998. Isolation, Identification and potential use of lead reduction from heavy metal polluted soil. Menufiya, J. Agric. Res., 23: 1461-1473.

Mahmood, M. 2010. Phytoextraction of heavy metal-the process and scope for remediation of contaminated soils. Soil Environ., 29: 91-109.

Paivoke, A.E.A. 2002. Soil lead alters phytase activity and mineral nutrient balance of Pisum sativum. Environ. Exp. Bot., 48: 61-73.

Prasad, J., Karmakar, S., Kumar, R. and Mishra, B. 2010. Influence of Integrated Nutrient Management on Yield and Soil Properties in Maize-Wheat Cropping System in an Alfisol of Jharkhand. $J$. Indian Society of Soil Sci., 8(2): 200204.

Steel, R.G. and Torrie, J.H. 1982. Principles and procedures of statistics. McGraw Hill Book Company, New Delhi110001.

Wagner, G.J. 1993. Accumulation of heavy metals in crop plants and its consequences to human health. $A d v$. Agron., 51: 173-177.

Yassen A.A., Nadia, B.M., Zaghloul, M.S. 2007. Role of some organic residues as tools for reducing heavy metals hazards in plant. W. J. Agri. Sci., 3(2): 204-207.

\section{How to cite this article:}

Patel, V.J., J.C. Patel, S.V. Rathod and Mori, B.J. 2017. Phosphorus uptake by Fodder Maize (Zea mays L.) Influenced by Different Levels of Lead and Farm Yard Manure Grown in Texturally Different Soils. Int.J.Curr.Microbiol.App.Sci. 6(8): 697-701. doi: https://doi.org/10.20546/ijcmas.2017.608.088 